\title{
THE IMPACTS OF ORGANIZATIONAL CULTURE ON KNOWLEDGE TRANSFERRING IN FDI ENTERPRISES IN VIETNAM
}

\author{
OS IMPACTOS DA CULTURA ORGANIZACIONAL NA TRANSFERÊNCIA DE \\ CONHECIMENTO EM EMPRESAS DE IED NO VIETN Ã
}

\section{LOS IMPACTOS DE LA CULTURA ORGANIZACIONAL EN LA TRANSFERENCIA DE CONOCIMIENTOS EN EMPRESAS DE IED EN VIETNAM}

Quoc Trung Pham ${ }^{1}$

Xuan Kieu Dinh ${ }^{2}$

\section{Cite as - American Psychological Association (APA)}

Pham, Q. T., \& Dinh, X. K. (2020, Sept./Dec.). The impacts of organizational culture on knowledge transferring in FDI enterprises in Vietnam. International Journal of Innovation - IJI, São Paulo, 8(3), 392-411. https://doi.org/10.5585/iji.v8i3.16059.

\begin{abstract}
Objective of the study: Knowledge transferring through Foreign Direct Investment (FDI) enterprises is a strategic policy for the economic development of many countries. However, in the case of Vietnam, the effectiveness of knowledge transfer in FDI enterprises is not clear, especially with the impact of cultural distance between foreign investors and local employees. The main goal of this study is to explore the impact of organizational culture on knowledge transferring in FDI enterprises in Vietnam.

Methodology/approach: Based on the original model of Parissa (2003), a research model has been proposed, in which the organizational cultural factors include cultural background, language ability, perceived cultural distance, learning style, and cultural openness. Quantitative research conducted through surveys with 109 respondents, who are working in FDI businesses in Ho Chi Minh City, Vietnam.

Originality/Relevance: This research focuses on the direct impact of cultural factors on knowledge transfer at individual level between foreign managers and local employees in Vietnam. Main results: Analytical results showed that three factors had a significant impact on the effectiveness of knowledge transfer, including Cultural openness, Language ability of foreign managers, and Communication distance.

Theoretical/methodological contributions: The study helps to test the measurement scales and contributes an empirical study in this field.

Social/management contributions: From these results, some managerial suggestions were made to support knowledge transferring between foreign managers and Vietnamese employees.
\end{abstract}

Keywords: Organizational culture. Knowledge transfer. FDI enterprises. Foreign managers. HCM City. Vietnam.

\footnotetext{
${ }^{1}$ Associate Professor at the Department of Management Information System, School of Industrial Management, University of Technology (VNU-HCM). Ho Chi Minh, Vietnam. pqtrung@ hcmut.edu.vn

${ }^{2}$ Manager at Shinryo Vietnam Company. MBA from the School of Industrial Management, University of Technology (VNU-HCM). Ho Chi Minh, Vietnam. xuankieu.dinh@gmail.com
} 


\section{Resumo}

Objetivo do estudo: A transferência de conhecimento por meio de empresas de Investimento Estrangeiro Direto (IED) é uma política estratégica para o desenvolvimento econômico de muitos países. No entanto, no caso do Vietnã, a eficácia da transferência de conhecimento em empresas de IED não é clara, especialmente com o impacto da distância cultural entre investidores estrangeiros e funcionários locais. O objetivo principal deste estudo é explorar o impacto da cultura organizacional na transferência de conhecimento em empresas de IED no Vietnã.

Metodologia / abordagem: Com base no modelo original de Parissa (2003), um modelo de pesquisa foi proposto, no qual os fatores culturais organizacionais incluem background cultural, habilidade linguística, distância cultural percebida, estilo de aprendizagem e abertura cultural. Pesquisa quantitativa realizada por meio de pesquisas com 109 entrevistados, que estão trabalhando em negócios de IDE na cidade de Ho Chi Minh, no Vietnã.

Originalidade / Relevância: Esta pesquisa enfoca o impacto direto de fatores culturais na transferência de conhecimento em nível individual entre gerentes estrangeiros e funcionários locais no Vietnã.

Principais resultados: Os resultados analíticos mostraram que três fatores tiveram um impacto significativo na eficácia da transferência de conhecimento, incluindo a abertura cultural, a capacidade linguística de gestores estrangeiros e a distância de comunicação.

Contribuições teórico-metodológicas: $\mathrm{O}$ estudo ajuda a testar as escalas de medição e contribui para um estudo empírico nesta área.

Contribuições sociais / gerenciais: A partir desses resultados, algumas sugestões gerenciais foram feitas para apoiar a transferência de conhecimento entre gerentes estrangeiros e funcionários vietnamitas.

Palavras-chave: Cultura organizacional. Transferência de conhecimento. Empresas de IDE. Gestores estrangeiros. Cidade HCM. Vietnã.

\section{Resumen}

Objetivo del estudio: La transferencia de conocimientos a través de empresas de Inversión Extranjera Directa (IED) es una política estratégica para el desarrollo económico de muchos países. Sin embargo, en el caso de Vietnam, la eficacia de la transferencia de conocimientos en las empresas de IED no está clara, especialmente con el impacto de la distancia cultural entre los inversores extranjeros y los empleados locales. El objetivo principal de este estudio es explorar el impacto de la cultura organizacional en la transferencia de conocimiento en empresas de IED en Vietnam.

Metodología / enfoque: Basado en el modelo original de Parissa (2003), se ha propuesto un modelo de investigación, en el que los factores culturales organizacionales incluyen antecedentes culturales, habilidad lingüística, distancia cultural percibida, estilo de aprendizaje y apertura cultural. Investigación cuantitativa realizada a través de encuestas con 109 encuestados, que trabajan en negocios de IED en Ciudad Ho Chi Minh, Vietnam.

Originalidad / Relevancia: esta investigación se centra en el impacto directo de los factores culturales en la transferencia de conocimiento a nivel individual entre gerentes extranjeros y empleados locales en Vietnam.

Principales resultados: Los resultados analíticos mostraron que tres factores tuvieron un impacto significativo en la efectividad de la transferencia de conocimiento, incluyendo la apertura cultural, la capacidad lingüística de los administradores extranjeros y la distancia de comunicación.

Contribuciones teóricas / metodológicas: El estudio ayuda a probar las escalas de medición y aporta un estudio empírico en este campo.

Contribuciones sociales / gerenciales: A partir de estos resultados, se hicieron algunas sugerencias gerenciales para apoyar la transferencia de conocimiento entre gerentes extranjeros y empleados vietnamitas.

Palabras clave: Cultura organizacional. Transferencia de conocimiento. Empresas de IED. Gerentes extranjeros. HCM City. Vietnam. 


\section{Introduction}

In the knowledge economy, knowledge becomes a strategic resource for the development of any organization. Moreover, for multinational companies, knowledge must be shared and transferred between staffs and business units for increasing the competitiveness and ensuring the success of the company. Recently, Vietnam has been considered the ideal destination for foreign direct investment (FDI) businesses, attracting a lot of foreign investors. However, the effectiveness of knowledge transfer in FDI enterprises is low, especially with the impact of cultural distance between foreign investors and local employees.

According to WTO, FDI business is from a foreign investor who has a property in a foreign country and property rights to it. So, FDI is a long-term investment of an individual or a company from this country to another country by establishing a business. That individual or company will hold the management rights of the business. Most of FDI businesses will recruit the local employees for reducing the operating cost and adapting to the local culture. However, there will be a knowledge gap between foreign managers and local staffs. Therefore, knowledge transferring is more important in FDI businesses.

Especially, in the Vietnam context, according to Pham (2017), some problems related to knowledge/ communication gap and cultural aspects could be realized as follows: (1) cultural difference between foreign manager and local staff makes it difficult for communication, (2) where there is a gap between practical knowledge and theoretical knowledge of local staff in applying foreign techniques or management styles, and (3) increasing trend of staff mobility and a lack of employee engagement in FDI businesses.

In order to ensure the success of FDI and to facilitate the knowledge flow between FDI's headquarter and subsidiaries, a knowledge-oriented culture should be established. Previous researches showed that organizational culture has a great impact on the success of knowledge transferring activities (Al-Alawi et al., 2007; Kimiz, 2005; Pham et al., 2017). With the multicultural working environment of FDI enterprises, cultural factors play a more important role in knowledge transferring from foreign managers to local employees. Currently, knowledge transferring inside FDI enterprises in Vietnam is not at the expected level, which may reduce the overall business performance of FDIs and the development of the whole economy.

Besides, there is a lack of research about the relationship between organizational culture and knowledge transferring in the context of FDI businesses in Vietnam. A research question could be formed as follows: "How organizational culture impacting on knowledge transferring 
in FDI enterprises in Vietnam?". Therefore, exploring the impact of organizational culture on the effectiveness of knowledge transferring in FDI enterprises in Vietnam is necessary for conducting.

Specific research objectives of this research could be summarized as follows: (1) Measuring the impact of the organizational culture of knowledge transferring of FDI businesses in Vietnam, and (2) Giving some recommendations for encouraging knowledge transferring in FDI businesses in Vietnam. The structure of this paper includes (2) concepts \& literature review, (3) research model and hypotheses, (4) research process, (5) analysis results, (6) discussion and implications, and (7) conclusion.

\section{Concepts \& literature review}

\subsection{Knowledge}

Knowledge is a familiarity, understanding or awareness about somebody or something, such as an object, information, descriptions, facts or skills, which is collected through education or experience by learning, discovering or perceiving (Kimiz, 2005). Knowledge is also said to be involved in the capacity of acknowledgment in human beings. In the context of FDI enterprises, knowledge refers to data, information, talent, and any intellectual assets necessary for doing business, including business secrets, know-how, patents, management skills, etc...Therefore, the competitive advantages of FDI enterprises come from the management of the knowledge flow between their branches around the world (Foss \& Pedersen, 2002).

\subsection{Knowledge Management}

Knowledge management $(\mathrm{KM})$ is defined as the system of the process in organizing and managing knowledge processes, such as identifying gaps of knowledge, acquiring, developing, storing, distributing, sharing and applying the knowledge. The processes of managing knowledge have become to be critical in enhancing the performance of organizations, that can either be directed to more creation or more effectiveness. Knowledge also supplies the foundation for innovation and enhancement in organizations. (Verburg and Andriessen, 2011).

According to Kimiz (2005), KM processes include (1) knowledge creating and capturing, (2) knowledge sharing and dissemination, and (3) knowledge acquisition and application. All of these processes are affected strongly by organizational culture because of the important role of people in these activities. 


\subsection{Knowledge Sharing/Transferring}

Knowledge sharing is an important step of the knowledge management process, in which one or both parties seeking and giving their knowledge, especially their tacit knowledge (know-how, attitude, experience, ideas...). Knowledge transferring is similar to knowledge sharing, but it focuses more on the effectiveness of this behavior, especially from the knowledge receiver's viewpoint. The effectiveness of knowledge transferring could be measured by the satisfaction of knowledge receiver, and the perception about the usefulness of knowledge received in decision making or problem-solving.

\subsection{Organizational Culture}

Organizational culture refers to the spiritual and physical environment of an organization that determines the attitude and behavior of its members. It includes tacit values, beliefs, and regulations of an organization. It could be seen through logos, slogans, customs, celebrations, identities of each member... Or anything that makes the organization different from other organizations (Kimiz, 2005).

Islam et al. (2011) showed that there was a strong relationship between organizational culture and knowledge sharing behavior of employees in service industries in Bangladesh. Based on a research of Mueller (2013), the impacts of organizational culture on knowledge transferring between members of projects in European countries were also confirmed. The above results indicated that organizational culture could be a suitable antecedent for knowledge transferring behavior in the context of FDI enterprises.

\subsection{FDI Enterprises in Vietnam}

According to Nguyen (2020), Vietnam had nearly 31,670 valid foreign-invested projects registered at $\$ 370.1$ billion, of which $58.3 \%$, or $\$ 215.6$ billion, has been disbursed. There are 136 nations and territories investing in Vietnam, including South Korea with \$68.6 billion in registered capital (18.5\%), Japan $\$ 59.7$ billion (16.1\%), followed by Singapore, Taiwan, and Hong Kong.

In 2018 and 2019, Vietnam was among the world's list of top 20 largest FDI attractors. FDIs have been providing jobs for 4.5 million direct local laborers and millions of indirect laborers. They hold 23-25\% of total national development investment capital, and create over $50 \%$ of industrial production value, while helping the country develop a modern financial and 
banking system. They also hold $70 \%$ of the nation's total export turnover, and are responsible for $20 \%$ of state budget and $20 \%$ of GDP. Currently, Vietnamese government considers FDI as a source of knowledge internalization and aims to draw more FDI into areas including exportoriented, energy and high-technology.

\subsection{Related Researches}

Individuals and organizations share several dimensions of context, such as: knowledge specific, culture specific, organization specific, person specific, and each of these dimensions can influence the knowledge transfer. A knowledge-oriented culture is clearly one of the most influential factors of successful knowledge transfer (Davenport et al. 1998), because a culture that promotes change and innovative behavior encourages active exchange of ideas and increased knowledge transfers. Therefore, this research focuses on examining the impact of cultural factors on knowledge transfer of FDIs in Vietnam.

Some researches related to knowledge transferring in FDI enterprises could be summarized as follows:

- Parissa (2003): This research explored the impact of culture in the knowledge transferring process of multinational companies. Based on literature review and expert interviews, Parissa proposed a research model, which focused on some cultural factors related to knowledge senders, such as cultural background, language ability, perceived cultural distance, learning style, and cultural openness. This research clarified the important role of knowledge senders in knowledge transferring. However, this research only mentioned about the indirect impact of cultural factors on knowledge transferring through the mediating role of knowledge processes. Besides, the proposed model was not tested by a quantitative research.

- Le et al. (2007): This research focused on the acquisition of tacit and explicit marketing knowledge from foreign partners in international joint ventures. Based on a literature review, a number of antecedents are identified and a model is tested using data obtained from 219 IJVs in Vietnam. Factors related to both knowledge seekers and knowledge holders, and the cultural distances between them are found to have a significant impact on the acquisition of marketing knowledge from foreign partners. This research conducted in Vietnam FDI context, but it still had some limitations, such as: focusing on marketing knowledge only, and not covering all aspects of the cultural factor. 
- Bastiaan (2009): This research focused on knowledge transferring in multinational companies, knowledge-intensive and project-based companies. In these companies, members of different groups/ projects have to communicate with each other from a far distance using various mediums. In this research, some cultural factors could be identified, including social similarity, interdependency, value variety, and professional variety. Although cultural differences were mentioned, the important role of knowledge givers (foreign managers) in knowledge transferring was not emphasized in this research.

- Pham and Luu (2016): This research explored the impact of organizational culture on knowledge sharing between employees in Vietnamese SMEs. Bases on a sample data of 418 employees working in Vietnamese SMEs, analysis results showed that knowledge sharing was affected by openness, team orientation, output orientation, and organizational structure. However, this research only focused on the local employees and managers.

- Nakagawa et al. (2018): This study examines whether the Japanese management style should be reconsidered in emerging markets, from the subsidiary control perspective. Using overseas subsidiary control theory, a hypothetical structure was developed and hypotheses were tested using survey data from Japanese subsidiaries. The results showed that the transfer of Japanese way did not improve subsidiary performance in emerging markets, but the departure from it did. In addition, the acceptance of local culture, headquarters' decentralization, and creating local partnership promote that departure. However, this research not directly examined the impact of organizational culture on knowledge transferring, but provided some other viewpoints on knowledge adoption in Japanese subsidiaries.

In general, the above researches showed the important role of cultural aspects from both knowledge senders and receivers in knowledge transferring. In this research, cultural aspects of the foreign managers (senders) are considered more important in determining the effectiveness of knowledge transferring in the context of FDI enterprises in Vietnam, because the cultural aspects of local staffs (receivers) is somehow similar and foreign managers are more active in the knowledge transferring process. Therefore, a research model emphasizing on the impact of cultural differences between foreign manager and local employees is necessary for fulfilling the research objectives. 


\section{Research model \& hypothesis}

From the above analysis, the research model of Parissa (2003) is considered more suitable for evaluating the impact of organizational culture on knowledge transferring in the context of FDI enterprises in Vietnam. So, it is selected and adapted for testing by a quantitative research. Difference from Parissa (2003), in this research, the direct impacts of organizational culture on knowledge transferring are examined rather than indirect impacts through knowledge process. Besides, "knowledge process" should be removed from the proposed model and "knowledge transferring" is used as dependent variable instead of "successful implementation of knowledge", which has the similar meaning. In summary, the suggested research model could be summarized in the following figure (Figure 1):

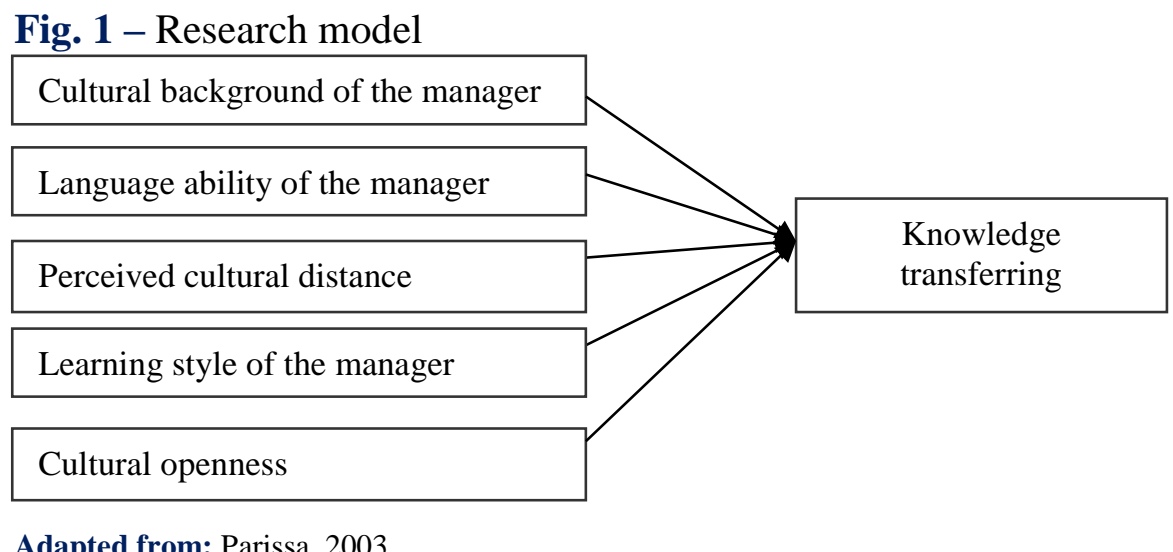

Cultural background of the manager: FDI businesses located in the country with a different culture from the original country of the owner/manager. Therefore, the difference in the cultural background of the foreign manager and local staff must have a negative impact on the knowledge transferring between foreign managers and local staffs (Williams et al., 1998). Besides, Le et al. (2007) indicated that the difference between cultural background of foreign managers and local employees impacts significantly on the effectiveness of knowledge acquisition in Vietnamese FDIs. Therefore, the hypothesis H1 could be stated as follows:

H1 (-): The difference in Cultural background of the manager has a negative impact on the knowledge transferring of FDI enterprises.

Language ability of the manager: Language ability refers to the ability to speak, to read, to listen and to understand the local language of the foreign manager (Redmond, 2000). The language skills of both manager and local staffs have a positive impact on the knowledge 
transferring effectiveness (Parissa, 2003). The higher the language ability of the foreign manager, the more likely he or she will prefer to communicate directly to his or her local employees. Therefore, the hypothesis $\mathrm{H} 2$ could be stated as follows:

$\mathrm{H} 2(+)$ : The language ability of the manager has a positive impact on the knowledge transferring of FDI enterprises.

Perceived cultural distance: This factor used to measure the personal cognition of the foreign manager about the difference between original culture and Vietnamese culture of FDI enterprises. Le et al. (2007) confirmed that perceived cultural distance could prevent information/knowledge flow between companies and partners. This relationship was also indicated in the results of other researches (Bastiaan, 2009). Therefore, the hypothesis H3 could be stated as follows:

H3 (-): The perceived cultural distance has a negative impact on the knowledge transferring of FDI enterprises.

Learning style of the manager: Learning occurred as a result of knowledge accumulation (Sparkes et al., 2000). Learning and teaching are processes affected by the culture of the learners or teachers. People in different cultures have different learning styles (Hall, 1973). The difference in learning style of manager and employees could lead to miscommunication and prevent the success of knowledge transfer. Therefore, the hypothesis H4 could be stated as follows:

H4 (-): The barrier in learning style has a negative impact on the knowledge transferring of FDI enterprises.

Cultural openness: The openness in organizational culture allows people in the different culture to interact with each other, and to learn from each other. The cultural openness of a manager could improve necessary skills and learn new methods of communication in the context of multinational companies (Griffith et al., 2001; Nakagawa et al., 2018). So, the cultural openness of the manager could have a positive impact on the knowledge flow of a multicultural environment. Besides, Pham and Luu (2016) confirmed that cultural openness has 
a significant impact on knowledge sharing between employees and managers in Vietnamese enterprises. Therefore, the hypothesis H5 could be stated as follows:

H5 (+): Cultural openness has a positive impact on the knowledge transferring of FDI enterprises.

\section{Research process}

This research was conducted in 2 steps: primary qualitative research for finalizing the questionnaire, and quantitative research for evaluating the research model.

Qualitative research: based on literature review and interview sessions with some experts to explore and modify the observed variables of measurement scales. Criteria for literature review are related researches focusing on knowledge sharing/ transferring. The scope focuses on organizational culture and FDIs. All of the original measurement scales are based on Parissa (2003), Doz et al. (1997), Kim (1988), Griffith et al. (2001), Redmond (2000), Hamel et al. (1989), Hall (1973), Hedlund et al. (1993), and Zander et al. (1995). The expert interview session was conducted with 16 managers and employees of an FDI enterprise in HCMC (in which, 7 people are foreign managers, 9 people are local employees). The original scales and final scales could be found in the appendix. Some main modifications in the measurement scales are as follows:

- The measurement scales must emphasize the difference between foreign manager and local employees. They must focus on individual level (not company level) of the cultural aspect.

- "Learning style of the manager" is difficult to evaluate in practice by local employees and should be explained more in the final questionnaire.

- Some phrases and words in "Cultural openness" and "Perceived cultural distance" should be modified to make it easy to understand in the context of FDI enterprises in Vietnam.

- Some scales of "Cultural background of the manager" seem to be similar to "Perceived cultural distance". They must be revised to be different and easy to evaluate by local employees. 
Quantitative research: After qualitative phase, a final questionnaire is formed to be used for quantitative analysis. The questionnaire includes 2 parts: (1) general information on respondents, such as: name, gender, age, position..., and (2) main questions using 5-levels Likert scales of 6 main factors of the research model. Then, sample data were collected conveniently from people who works for FDI enterprises in Vietnam, using both online and offline channels. After that, the measurement scales could be tested and the research model would be evaluated. The target sample size should be more than 100 employees ( 5 times of the questions in the questionnaire).

Collected data will be processed and analyzed by SPSS 20.0 software. Some data analysis processes could be summarized as follows: Descriptive statistics of samples; Cronbach's Alpha analysis for testing the reliability of measurement scales; Exploratory factor analysis (EFA) for testing the discriminant and consistency of the measurement scales; Multiple regression analysis for testing the hypotheses; ANOVA, Independent Sample T-test for testing the impact of some demographic factors on the dependent variable (Nguyen, 2013).

\section{Analysis results}

\subsection{Sample Description}

The finalized questionnaire was used for collecting quantitative data during one (1) month by both methods: online questionnaire (sent links through e-mail and online communities) and paper-based questionnaire (sent directly to friends and MBA students who are working in FDI enterprises in Ho Chi Minh city). For online method, each respondent is working for different companies. For offline method, a maximum of 3 questionnaires is sent for each FDI enterprise. In total, 150 paper questionnaires were scattered for about 50 FDI enterprises in Ho Chi Minh City, Vietnam. After cleaning phase (lack of information, the same answer for all questions, inconsistent...), there are 109 valid samples collected (in which 60 from offline channel and 49 from online channel) and they are used for data analysis. Some descriptive statistics of the sample data could be summarized as follows:

By gender of respondents, there are $67 \%$ of male and $33 \%$ of female. This rate is similar to the whole population of employees in FDI enterprises in HCMC. By age, the majority group is $25-30$ years old $(58.7 \%)$, the second one is $31-40$ years old $(34.9 \%)$, then, $18-25$ years old $(6.4 \%)$. By the years of experience of respondents, the highest group is 3-5 years (34.9\%), then, $1-3$ years $(33.0 \%),>5$ years $(18.3 \%),<1$ year $(13.8 \%)$. By job position, the majority group is employees (65\%), following by the team/group leaders (33\%), and head of 
departments/projects (11\%). Although the majority of respondents are employees, their answers are suitable for understanding the viewpoint of both employees and managers, and they are useful for evaluating the impact of organizational culture on the success of knowledge transferring in FDI enterprises. By income, 5-10 million VND is the highest group (40.4\%), then, 10-15 million VND (36.7\%), > 15 million VND (17.4\%), and finally, < 5 million VND. (5.5\%). By FDI owner, the highest group in Japan (67.9\%), then, United States of America (7.3\%), Korea (6.4\%), Switzerland (4.6\%), and other countries (13.8\%).

\subsection{Cronbach's Alpha Analysis}

The reliability of the measurement scales is evaluated by Cronbach's alpha coefficient. If the Cronbach's alpha coefficient of the factor $>0.6$ and item-total correlation $>0.3$, it is considered reliable, if not, it should be removed (Hoang et al., 2008).

According to the result, Cronbach's alpha of "Perceived cultural distance" is 0.507 $(<0.6)$, and item-total correlation of 1 variable is $0.117(<0.3)$, so, it must be removed. After removing this variable, the new Cronbach's alpha is 0.644 (acceptable). Cronbach's alpha coefficients of other scales are $>0.6$, and item-total correlations are $>0.3$, so they are all maintained for EFA analysis.

\subsection{Exploratory Factor Analysis (EFA)}

According to Hoang et al. (2008), EFA result is considered suitable if KMA (KaiserMeyer-Olkin) $>0.5$, sig. value of Bartlett's test $<0.05$, all variables must have factors loading $>0.5$, Eigenvalue $>1$ and Cumulative Extraction Variance $>50 \%$. In this research, Principal component method is used with a Varimax rotation technique for exploratory factor analysis of independent variables. After 3 rounds of running EFA, all criteria are satisfied. The KMO coefficient is $0.71(>0.5)$, and sig. value of Bartlett's test is $0.00(<0.05)$. The final EFA result could be summarized in the following table (Table 1). 
Table 1 - The final efa result

\begin{tabular}{|c|r|r|r|r|}
\hline & \multicolumn{5}{|c|}{ Factors } \\
\hline & 1 & 2 & 3 & 4 \\
\hline OP2 & $\mathbf{. 8 3 7}$ & & & \\
\hline OP4 & $\mathbf{. 7 7 7}$ & & & \\
\hline OP1 & $\mathbf{. 7 4 5}$ & & & \\
\hline OP3 & $\mathbf{. 6 8 7}$ & & & \\
\hline LA2 & & $\mathbf{. 8 5 5}$ & & \\
\hline LA3 & & $\mathbf{. 8 0 8}$ & & \\
\hline LA1 & & $\mathbf{. 6 4 2}$ & & \\
\hline LA4 & & $\mathbf{. 5 9 6}$ & & \\
\hline CD3 & & & $\mathbf{. 8 3 1}$ & \\
\hline CD2 & & & $\mathbf{. 0 3}$ & \\
\hline CB1 & & & & $\mathbf{. 8 6 4}$ \\
\hline CB2 & & & & $\mathbf{. 8 5 5}$ \\
\hline
\end{tabular}

Extraction method: Principal component analysis.

Rotation method: Varimax with Kaiser normalization.

Based on the EFA result of independent factors, factor "Learning style of the manager" is completely removed (factor loadings $<0.5$ ). After removing some variables, there are 4 maintaining factors, including: "Cultural openness", "Language ability of the manager", "Perceived cultural distance", and "Cultural background of the manager". The EFA result for dependent factor showed that all variables satisfy the criteria and belong to separated factors.

\subsection{The Revised Model}

According to the EFA results, in the revised model, factor "Learning style of the manager" should be removed from the original model, and hypothesis $\mathrm{H} 4$ will be removed also. In general, the research model could be revised as in the following figure (Figure 2).

Fig. 2 - The revised research model

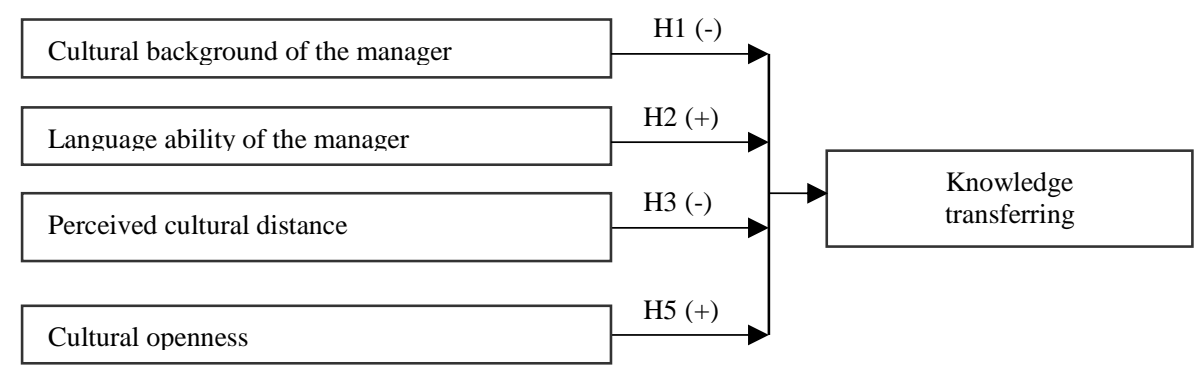

Source: From analysis results. 


\subsection{Multiple regression analysis}

Applying regression analysis for testing the impact of 4 independent factors on the effectiveness of knowledge transferring in FDI enterprises. The result showed that sig. value of "Cultural background of manager" $>0.05$, so that, $\mathrm{H} 1$ is not supported. The sig. values for other factors are less than 0.05 , so that $\mathrm{H} 2, \mathrm{H} 3$, and $\mathrm{H} 5$ are supported by the sample data (at a $95 \%$ significance level). The adjusted R-square is 0.619 , which means that the independent variables in the model could explain for nearly $62 \%$ in the variances of knowledge transferring in FDI enterprises.

Testing the regression model assumptions: The scattering plot between standardized predicted value and standardized residual showed that the values were scattered randomly. Therefore, the linear relationship assumption is acceptable. The size of standardized residual on the plot was not increased or decreased by the standardized predicted value. So, the assumption on unchanged error-variance is acceptable. Besides, the results on the Q-Q Plot showed that the distribution of standardized residual is normal distribution. So, the assumption about the normal distribution of residual is acceptable. In summary, the regression analysis result could be used for predicting the knowledge transferring behavior of FDI enterprises.

In general, the regression analysis result could be summarized in this formula: Knowledge transferring $=0.563 *$ Cultural openness $+0.271 *$ Language ability of manager $0.228 *$ Perceived cultural distance. This formula helps to predict the success/ failure of knowledge transfer in FDIs by 3 main factors: cultural openness, language ability of manager, and cultural distance. Therefore, in order to ensure the success of knowledge transferring in FDI enterprises, foreign managers should create an open culture, improve their language ability, and reduce cultural distance between foreign managers and local employees.

\subsection{Anova \& t-Test}

By gender, according to the result of independent sample t-test, there is no difference in knowledge transferring between the male and female group.

Based on One-way ANOVA test, there is no difference in knowledge transferring between age groups, job positions, and income groups. However, employees who worked for more than 5 years seem to have higher knowledge transferring effectiveness than employees who worked for less than 1 year. 


\section{Discussion \& implications}

In general, the above results are similar to Le et al. (2007) in confirming the important role of cultural distance in knowledge transferring in FDI enterprises. According to De-long \& Fahey (2000), cultures heavily influence what is perceived as useful, important, or valid knowledge in an organization, so cultural distance could be a barrier to knowledge management. However, the absolute value of this impact is not as high as expected. The reason could be in the sample data, most of FDI enterprises in this sample belong to Japan or Korea $(\sim 75 \%)$, which has a similar culture to Vietnam.

Besides, in this research, "cultural openness" is found to have the strongest impact on knowledge transferring effectiveness. So, establishing an open organizational culture is very important in ensuring the success of knowledge transfer in FDI enterprises. An open culture requires the company to pay attention more to creating a friendly environment for sharing, conversation and collaboration between foreign managers and local employees. This result is similar to Pham \& Luu (2016), in which, cultural openness plays an important role in encouraging knowledge sharing between employees.

Another factor to be considered is the Language ability of the manager. In the context of FDI enterprises, language skills of foreign manager are very important in ensuring the effectiveness of communication and knowledge sharing between managers and employees. This requires the foreign managers to improve their English skills (if they come from a nonnative English speaking country) as well as to learn some Vietnamese language. The mean analysis of the sample showed that foreign managers are fairly weak in listening and speaking skills (3.6/ 5), and these skills must be improved for better communication and effective knowledge transferring.

However, in this research, the impact of 2 other factors ("learning style of manager" and "cultural background of manager") could not be tested and supported by the sample data. The reason could be in the bias of the data collection process (68\% of FDI businesses are Japanese ones), so the testing result is insignificant because there is a lack of variety in learning styles and cultural background of the manager. Moreover, these factors could be difficult to evaluate by the local employees, which is the majority $(65 \%)$ in the sample. These difficulties are also recognized during the quantitative research.

Based on the above analysis results, some managerial implications for improving the effectiveness of knowledge transferring in FDI enterprises could be suggested as follows: 
Establishing an open organizational culture: Open culture requires both sides (employees and managers) accept the differences and sympathize with each other in doing the job. So, organizing some sports activities, social events, team-building events... could help to create a friendly culture and to connect local employees and foreign managers. These events and activities, if managed well, could help to establish an open culture gradually. Some special celebrations, such as Anniversary, Women's Day, Christmas Day, Year-End Party..., must be used to connect people and to encourage a sharing cultures. Besides, the foreign managers should encourage new ideas from employees, and accept the failure at some level.

Improving language ability of foreign manager: Language ability is very important for improving the effectiveness of the internal communication. The company should have training programs for improving the language ability of both managers and employees. Foreign managers are encouraged to learn the Vietnamese language, and local employees are encouraged to learn the language of FDI manager besides English. FDI enterprises should support their employees in improving their language ability (financial support, or absence for learning time). Organizing an English club could be a good option for improving the language skills of both managers and employees.

Reducing perceived cultural distance: In order to reduce the cultural distance, orientation sessions and clearly stated guidelines should be used for introduction about the culture and general regulations in communication and accepted behavior. Besides, establishing a document-base for consistently storing documents, especially technical documents for each department, is necessary for reducing the cultural distance. All information/knowledge should be shared on the intranet or the company website for better communication. Periodically, cultural exchange activities should be organized for local staffs to understand more about the culture of foreign managers, and vice versa.

Other recommendations: The ANOVA analysis showed that there is a difference in knowledge transferring between a group of employees working for more than 5 years and less than 1 year. So, the FDI enterprises should have different policies to 2 groups of employees: newcomers, and long-time workers. The newcomers should be encouraged to learn and capture knowledge more, while the long-time workers, who have some experience, should be encouraged to share their knowledge and to help the newcomers in their job. Because most of FDI enterprises in the sample belong to Japan, 
lifelong recruitment policy is suitable for encouraging the employees work for a long time and to share their knowledge with other employees in the company.

\section{Conclusion and future research}

Based on previous research of Parissa (2003), some cultural factors affecting on the effectiveness of knowledge sharing in FDI enterprises are realized, including cultural background of the manager, language ability of the manager, perceived cultural distance, learning style of the manager, and cultural openness. After quantitative data analysis with a sample of 109 employees and managers in FDI enterprises in Vietnam, 3 factors are confirmed to have impacts on knowledge sharing of FDI enterprises, which is sorted by descending of beta coefficients: cultural openness (beta $=0.563$ ), the language ability of the manager (beta=0.271), and perceived cultural distance (beta $=-0.228$ ).

This results confirmed the strong impact of organizational culture on knowledge transfer in the context of FDI enterprises in Vietnam, in which cultural openness (open conversation, creativity, and difference acceptability) was realized the most important factor influencing the success of knowledge transfer.

According to this result, some managerial implications have been suggested for improving the effectiveness of knowledge transferring in FDI enterprises in Vietnam. The suggestion could be summarized as follows: (1) establishing an open organizational culture by organizing social activities and cultural events, (2) improving language ability of foreign manager, especially listening and speaking skills, (3) reducing the cultural distance by externalizing all regulations and sharing cultural expectancy.

However, there are some limitations of this research as follows:

- Small sample size and limited in Ho Chi Minh City could reduce the generalization of this result.

- Adjusted R-square of regression analysis is 0.62 , this means some other factors should be included to increase the explanation possibility of the model.

- A specific type of FDI enterprises or type of knowledge sharing should be examined for more specific managerial suggestions.

Some implications for future research could be summarized as follows:

- Conduct the research with a bigger sample size, or scattering data in various areas in Vietnam 
- Examine some other factors affecting on the knowledge transferring effectiveness in FDI enterprises, such as HRM, innovation, leadership...

- Focus on a specific type of FDI enterprises, industries, or knowledge processes...

\section{References}

Al-Alawi, I.A., Al-Marzooqi, Y.N., \& Mohammed, F.Y. (2007). Organizational culture and knowledge sharing: critical success factors. Journal Knowledge Management, 11 (2), 2242.

Bastiaan, R. (2009). Sharing knowledge, being different and working as a team. Knowledge Management Research \& Practice, 7, 4-14.

Davenport, T.H., De-Long, D.W., \& Beers, M.C. (1998). Building Successful Knowledge Management Projects. Sloan Management Review. Winter 1998, 39 (2), 43.

De-Long, D.W., \& Fahey, L. (2000). Diagnosing cultural barriers to knowledge management. The Academy of Management Executive, 14 (4), 113-127.

Doz, Y., \& Santos, J.F.P. (1997). On the management of knowledge: from the transparency of collocation and co-setting to the quandary of dispersion and differentiation. Institut Europeen d'Administration des Affaires (INSEAD).

Foss, N. J., \& Pedersen, T. (2002). Transferring Knowledge in MNCs: The Role of Sources of Subsidiary Knowledge and Organizational Context. Journal of International Management, 8 (2002), 49-67.

Griffith, D. A., \& Harvey, M. G. (2001). Executive insights: An intercultural communication model for use in global inter-organizational networks. Journal of International Marketing, $9(3), 87-103$.

Hall, E. T. (1973). The Silent Language. New York: Doubleday Anchor Book.

Hamel, G., Doz, Y., \& Prahalad, C. K. (1989). Collaborate with your competitors, and win. Harvard Business Review, 67 (2), 133-139.

Hedlund, G., \& Nonaka, I. (1993). Models of Knowledge Management in the West and Japan. In (P. Lorange): Implementing strategic processes: Change, learning, and Co-operation Basil Blackwell. Oxford, UK.

Hoang, T. \& Chu, N.M.N. (2008). Phân tích dũ liệu nghiên cúu với SPSS (Tập 1 và 2), Nhà Xuất Bản Hồng Đức.

Islam, Z., Hassan, I., Ahmed, S. \& Ahmed, S.M. (2011). Organizational Culture and Knowledge Sharing: Empirical Evidence from Service Organizations, African Journal of Business Management, 5 (14), 5900-5909 
Kim, Y. (1988). Communication and Cross-Cultural Adaptation: An Integrative Theory. Multilingual Matters, Clevedon, England.

Kimiz, D. (2005). Knowledge Management in Theory and Practice, Oxford, Elsevier, UK.

Le, N.H. \& Felicitas, E. (2007). Acquiring tacit and explicit marketing knowledge from foreign partners in IJVs. Journal of Business Research, 60 (2007), 1152-1165

Mueller, J. (2013). A specific knowledge culture: Cultural antecedents for knowledge sharing between project teams, European Management Journal, 32 (2), 190-202.

Nakagawa, K., Nakagawa, M., Fukuchi, H., Sasaki, M. \& Tada, K. (2018). Japanese Management Styles: to Change or Not to Change? A Subsidiary Control Perspective. Journal of International Business and Economics, 6 (2), 1-10.

Nguyen, D.T. (2013). Phưong pháp nghiên cứu khoa học trong kinh doanh. Nhà Xuất Bản Lao Động Xã Hội.

Nguyen, M. (2020). Harnessing further FDI to Vietnam. Vietnam Investment Review. Retrieved from: https://www.vir.com.vn/harnessing-further-fdi-to-vietnam-75879.html (Accessed on 02/05/2020).

Parissa, H. (2003). Does Culture Really Matter? Culture on the Knowledge Transfer Process within Multinational Corporations. Vienna University of Economics and Business Administration, Vienna, Austria.

Pham, Q. T. (2017). A Knowledge Management Approach for Ensuring the Success of IT Industries in Vietnam. New York: Nova Science Publishers, Inc.

Pham, QT., \& Luu, CH. (2016). Impact of organizational culture on knowledge sharing behavior of employees in Vietnamese SME. Scientific Journal of Open University - HCMC, 5 (50), 87-98.

Pham, Q. T. \& Nguyen, D. T. (2017). An Empirical Investigation of Knowledge Management in Vietnamese SMEs. The 17th International Conference on Computational Science and Its Applications (ICCSA), 2017.

Redmond, M. V. (2000). Cultural Distance as a Mediating Factors between Stress and Intercultural Communication Competence. International Journal of Intercultural Relations, 24, 151-159.

Sparkes, J. R. and Miyake, M. (2000). Knowledge Transfer and Human Resource Development Practices: Japanese Firms in Brazil and Mexico. International Business Review, 9, 599 - 612.

Verburg, R., \& Andriessen, E. (2011). A Typology of Knowledge Sharing Networks in Practice. Knowledge and Process Management, 18(1), 34-44.

Williams, J. D., Han, S.-L., \& Qualls, W. J. (1998). A Conceptual Model and Study of CrossCultural Business Relationships. Journal of Business Research, 42, 135-143. 
Zander, U., \& Kogut, B. (1995). Knowledge and the Speed of the Transfer and Imitations of Organizational Capabilities: An Empirical Test. Organization Science, 6 (1), 76-92.

\section{Appendix}

\section{A-Original measurement scales}

\begin{tabular}{|c|c|c|}
\hline Factor & Measurement scales & Source \\
\hline \multirow{3}{*}{$\begin{array}{l}\text { Cultural } \\
\text { context }\end{array}$} & Difference in the habit & \multirow{3}{*}{ Parissa (2003) } \\
\hline & Difference in traditional customs & \\
\hline & Misunderstanding in communication & \\
\hline \multirow{4}{*}{$\begin{array}{l}\text { Language } \\
\text { ability }\end{array}$} & Speaking skills & \multirow{2}{*}{ Redmond (2000) } \\
\hline & Listening and comprehension skills & \\
\hline & Writing skills & \multirow{2}{*}{ Doz et al. (1997) } \\
\hline & Verbal communication skills & \\
\hline \multirow{3}{*}{$\begin{array}{l}\text { Cultural } \\
\text { distance }\end{array}$} & Communication ability & Kim (1988) \\
\hline & The cultural gaps are big & Parissa (2003) \\
\hline & The shared information is inconsistent & Griffith et al. (2001) \\
\hline \multirow{4}{*}{$\begin{array}{l}\text { Cultural } \\
\text { openness }\end{array}$} & Various open conversion chances & \multirow{3}{*}{ Griffith et al. (2001) } \\
\hline & The willingness in knowledge sharing & \\
\hline & Finding an effective communication method & \\
\hline & The shared information is clear & Parissa (2003) \\
\hline \multirow{4}{*}{$\begin{array}{l}\text { Learning } \\
\text { style }\end{array}$} & The difference in learning style & Hall (1973) \\
\hline & Learning style focusing more on listening & \multirow{3}{*}{ Hedlund et al. (1993) } \\
\hline & Learning style focusing on practical experience & \\
\hline & Learning style focusing on lifelong working & \\
\hline \multirow{3}{*}{$\begin{array}{c}\text { Knowledge } \\
\text { transfer }\end{array}$} & Satisfaction in receiving new knowledge & \multirow{2}{*}{ Parissa (2003) } \\
\hline & Easy to understand the requirements & \\
\hline & Easy to apply knowledge in a new context & Zander et al. (1995) \\
\hline
\end{tabular}

\section{$B$ - Final measurement scales}

\begin{tabular}{|l|l|}
\hline Code & \multicolumn{1}{|c|}{ Measurement scales } \\
\hline CB1 & The difference in the habit of manager and local employees is high \\
\hline CB2 & Difference in traditional customs of manager and local employees is high \\
\hline CB3 & Difference in communication style of manager and local employees is high \\
\hline LA1 & Speaking skills of the manager are good \\
\hline LA2 & Listening skills of the manager are good \\
\hline LA3 & Writing skills of the manager are good \\
\hline LA4 & Verbal communication skills of the manager are good \\
\hline CD1 & The perceived difference in cultural distance is high \\
\hline CD2 & The perceived communication gaps are high \\
\hline CD3 & The shared information in the organization is inconsistent \\
\hline OP1 & Open conversion chance between foreign manager and local employee is high \\
\hline OP2 & The willingness in knowledge sharing of the foreign manager is high \\
\hline OP3 & The shared information from the foreign manager is in the details \\
\hline OP4 & The collaboration in finding an effective communication method is good \\
\hline LS1 & The difference in learning style of the foreign manager is high \\
\hline LS2 & Learning style of manager focusing more on listening (not talking) \\
\hline LS3 & The learning style of manager based on practical experience (not an abstraction) \\
\hline LS4 & Learning style of manager focusing on lifelong working (not task specific) \\
\hline KT1 & Satisfaction in receiving new knowledge \\
\hline KT2 & Feel easy in doing tasks according to the foreign manager's requirements \\
\hline KT3 & Feel easy in applying acquired knowledge in various contexts \\
\hline
\end{tabular}

